Kredo 4 (2021)
KREDO: Jurnal Ilmiah Bahasa dan Sastra
Terakreditasi Sinta 4 berdasarkan Keputusan
Direktorat Jenderal Penguatan Riset dan
Pengembangan, Kementerian Riset, Teknologi dan
Pendidikan Tinggi Republik Indonesia
Nomor: 23/E/KPT/2019.08 Agustus 2019
https://jurnal.umk.ac.id/index.php/kredo/index

\title{
TEKNIK WARMING UP FOR READING: STRATEGI BELAJAR UNTUK MELEJITKAN KEMAMPUAN MEMBACA PEMAHAMAN PESERTA DIDIK
}

\author{
Rukayah $^{1}$, Abdul Hafid ${ }^{2}$, Aziz Thaba ${ }^{3}$ \\ rukayah@unm.ac.id \\ 1 dan 2 Universitas Negeri Makassar, Indonesia \\ ${ }^{3}$ Lembaga Swadaya Penelitian dan Pengembangan Pendidikan (LSP3) Matutu, Indonesia
}

Info Artikel
Sejarah Artikel
Diterima
22 Februari 2021
Disetujui
8 April 2021
Dipublikasikan
9 April 2021
Keywords
Comprehension Reading
Skills, Warming Up for
Reading

Kata Kunci

Keterampilan

Membaca

Pemahaman,

Warming Up for

Reading
: : This research is a class action research (Classroom Action Research) which aims to improve reading comprehension skills through the Warming Up for Reading technique in class VII.B students of SMP Muhammadiyah 5 Makassar. The subjects of this study were 34 students of class VII B SMP Muhammadiyah 5 Makassar in the 2018/2019 academic year. This research was conducted in two cycles, each cycle carried out in 4 meetings including at the end of each cycle. Data collection was carried out using the final learning test at the end of each cycle, observations made during the learning process and through questionnaire data on student responses given at the end of each cycle. The collected data consisted of quantitative and qualitative data which were analyzed using quantitative descriptive analysis and qualitative descriptive analysis. The results showed that in the first cycle who completed individually from 34 students only 13 people or $38.23 \%$. Meanwhile, 21 students who have not completed or 61 , $76 \%$, classically have not met because the class average score is $66.87 \%$. In cycle II, of the 34 students there were 26 students or $76.47 \%$ who had completed and 8 students who had not completed completeness or $23.52 \%$ classically had been fulfilled, namely the average value : obtained was $80.88 \%$ or in the high category. Based on these results, it can be concluded that the Reading Comprehension Ability of Class VII B Students of SMP Muhammadiyah 5 Makassar through the Warming Up for Reading Technique has increased.

\footnotetext{
Abstrak

Penelitian ini adalah penelitian tindakan kelas (Classroom Action Research) yang bertujuan untuk meningkatkan kemampuan membaca pemahaman melalui teknik Warming Up for Reading pada siswa kelas VII $_{\text {B }}$ SMP Muhammadiyah 5 Makassar. Subjek penelitian ini adalah siswa kelas VII B SMP Muhammadiyah 5 Makassar tahun ajaran 2018/2019 sebanyak 34 siswa. Penelitian ini dilaksanakan dalam dua siklus, masing-masing siklus dilaksanakan sebanyak 4 kali pertemuan termasuk pada setiap akhir siklus. Pengumpulan data dilaksanakan dengan menggunakan tes akhir belajar pada setiap akhir siklus, observasi yang dilakukan pada saat proses pembelajaran berlangsung dan melalui data angket respons siswa yang diberikan pada setiap akhir siklus. Data yang terkumpul terdiri atas data kuantitatif dan kualitatif yang dianalisis dengan menggunakan analisis deskriptif kuantitatif dan deskriptif kualitatif. Hasil penelitian menunjukkan bahwa pada siklus I yang tuntas secara individual dari 34 siswa hanya 13 orang atau $38.23 \%$. Sedangkan 21 siswa yang belum tuntas atau 61, 76\%, Secara klasikal belum terpenuhi karena nilai rata-rata kelas diperoleh sebesar 66,87\%. Pada siklus II, dari 34 siswa terdapat 26 siswa atau $76,47 \%$ yang tuntas dan 8 siswa yang belum mencapi ketuntasan atau $23,52 \%$ secara klasikal sudah terpenuhi yaitu nilai rata-rata yang diperoleh sebesar $80,88 \%$ atau berada dalam kategori tinggi. Berdasarkan hasil penelitian tersebut, dapat disimpulkan Kemampuan Membaca Pemahaman Siswa Kelas VII B SMP Muhammadiyah 5 Makassar melalui Teknik Warming Up for Reading mengalami peningkatan.
} 


Kredo 4 (2021)
KREDO: Jurnal Ilmiah Bahasa dan Sastra
Terakreditasi Sinta 4 berdasarkan Keputusan
Direktorat Jenderal Penguatan Riset dan
Pengembangan, Kementerian Riset, Teknologi dan
Pendidikan Tinggi Republik Indonesia
Nomor: 23/E/KPT/2019.08 Agustus 2019
https://jurnal.umk.ac.id/index.php/kredo/index

\section{PENDAHULUAN}

Keterampilan membaca pemahaman merupakan salah satu kemampuan membaca yang mesti dikuasai oleh siswa SMP sebab terdapat dalam Kurikulum 2013 (K13). Tarigan (2008) menyatakan bahwa yang dimaksudkan dengan membaca pemahaman tersebut ialah jenis membaca yang mempunyai tujuan untuk memahami resensi kritis, pemahaman mengenai norma-norma/standar-standar kesastraan, pemahaman mengenai drama tulis, dan memahami aturan mengenai fiksi.

Berdasarkan hasil observasi awal, umumnya di SMP Muhammadiyah 5 Makassar masih menggunakan model pembelajaran tradisional atau model lama dalam pembelajaran membaca. Peserta didik ditugasi untuk membaca buku mata pelajaran selanjutnya mereka diberi tugas untuk menyelesaikan beberapa soal yang sebelumnya telah dipersiapkan, pokok-pokok cerita yang termuat dalam bacaan tersebut tidak dianalisis sebelum dikerjakan, utamanya pada kegiatan membaca pemahaman sehingga siswa sepenuhnya tidak memahami materi yang disampaikan oleh guru. Agar bahan bacaan (terutama bahan ajar) yang dibaca oleh peserta didik benar-benar dapat dipahami, maka pembelajaran membaca yang masih menggunakan metode atau teknik pembelajaran tradisional atau lama harus ditinggalkan dan digantikan dengan suatu teknik baru sehingga peserta didik memahami bahan ajar atau teks lain yang dibacanya.

Salah satu teknik pembelajaran membaca pemahaman yang dapat menggabungkan pembelajaran yang bermakna dengan proses membaca adalah teknik Warming Up for Reading. Sebab teknik ini sangat sederhana dan salah satu media yang digunakan dalam kegiatannya adalah menggunakan secarik kertas kerja (worksheet). Instruksi yang jelas dimuat dalam lembar kertas kerja tersebut, sehingga mampu memberikan suatu gambaran yang jelas bahwa secara mandiri teknik ini dapat dilakukan yang menyebabkan siswa sebagi pusat dari kegiatan belajar mengajar. Jenis dan nama tugas (individu ataupun kelompok) tercantum dalam kertas ini sehingga dalam melakukan kegiatan monitoring dan evaluasi pembelajaran guru dimudahkan.

Zuchdi (2008) menyatakan bahwa dalam pembelajaran membaca, guru dapat menggunakan beberapa teknik yang bisa dijadikan sebagai alternatif dalam proses pembelajaran misalnya teknik Predict, Organize, Rehearse, Practice, Evaluate (PORPE), teknik (KWL), teknik Prereading Plan (PreP), teknik Predict, Organize, Rehearse, teknik (KWL), dan teknik Extending Concept Through Language Activities (ECOLA). Selain teknik membaca yan 


Kredo 4 (2021)
KREDO: Jurnal Ilmiah Bahasa dan Sastra
Terakreditasi Sinta 4 berdasarkan Keputusan
Direktorat Jenderal Penguatan Riset dan
Pengembangan, Kementerian Riset, Teknologi dan
Pendidikan Tinggi Republik Indonesia
Nomor: 23/E/KPT/2019.08 Agustus 2019
https://jurnal.umk.ac.id/index.php/kredo/index

telah disebutkan di atas adapula teknik Warming Up for Reading yang dikemukakan oleh Sequero (1998). Dalam pembelajaran membaca khususnya membaca pemahaman, teknik ini lebih efektif, kreatif dan inovatif digunakan (Hal ini sejalan dengan laporan hasil penelitian (Fradkin, Zazryn, and Smoliga 2010; Sequero 1998; Sunarti 2020). Teknik Warming Up for Reading oleh Sequero (1998) akan digunakan dalam penelitian ini. Penggunaan teknik ini dalam penelitian ini disebabkan dalam pembelajaran membaca pemahaman di SMP Muhammadiyah 5 Makassar khususnya pada siswa kelas VII belum pernah digunakan dalam proses pembelajaran.

Meskipun petunjuk kegiatan dan manfaat dari penggunaan teknik Warming Up for Reading Sequero (1998) ini secara jelas telah tercantum pada kertas kerja, akan tetapi guru harus tetap memberi penjelasan kepada peserta didik. Kegiatan ini memiliki tujuan agar antara guru dan peserta didik selalu ada kedekatan dan dalam pembelajaran saling membantu. Ada empat komponen dasar dalam proses membaca melalui penggunaan teknik warming up for reading, yaitu: (1) kosa kata dikembangkan (2) apa yang akan muncul dalam bacaan tesebut diprediksikan (3) informasi yang akan siswa teriam diantisipasi, sehingga proses evaluasi terjadi, dan (4) sebelum informasi tertentu dicari, siswa terlebih dahulu mencari informasi umum. Selain bermanfaat sebagai kegiatan pramembaca, salah satu manfaat yang dimiliki oleh teknik ini adalah membuat suatu pembelajaran lebih memiliki suatu makna, hal ini terjadi dikarenakan teknik ini mampu menjadikan instrumen untuk mengaktifkan dan menggali kembali pengetahuan dasar yang dimiliki peserta didik. Tujuan dari penggunaan teknik ini adalah agar pemahaman terhadap isi bacaan diperoleh oleh pembaca.

\section{KAJIAN TEORI}

\section{A. Hakikat Membaca}

Salah satu keterampilan yang erat kaitannya dengan keterampilan dasar terpenting manusia (berbahasa) yaitu keterampilan membaca. Membaca merupakan kegiatan yang memiliki sifat reseptif, suatu bentuk penyerapan yang aktif. Secara aktif pikiran dan mental dilibatkan dalam kegiatan membaca, tidak hanya melibatkan kegiatan fisik saja, yang berarti bahwa aktivitas membaca tidak hanya kegiatan membaca saja akan tetapi kegiatan membaca merupakan suatu kegiatan yang seluruh indera pembaca dilibatkan yang dimaksudkan agar apa yang dibaca dapat diketahui isi dan maksud dari wacana tersebut (Agunawan 2009; Tampubolon 1990; Zuchdi 2008).

Kegiatan membaca merupakan aktivitas mental memahami apa yang dituturkan pihak lain melalui saran 


Kredo 4 (2021)
KREDO: Jurnal Ilmiah Bahasa dan Sastra
Terakreditasi Sinta 4 berdasarkan Keputusan
Direktorat Jenderal Penguatan Riset dan
Pengembangan, Kementerian Riset, Teknologi dan
Pendidikan Tinggi Republik Indonesia
Nomor: 23/E/KPT/2019.08 Agustus 2019
https://jurnal.umk.ac.id/index.php/kredo/index

tulisan. Jika dalam kegiatan menyimak diperlukan pengetahuan tentang sistem bunyi bahasa yang bersangkutan, dalam kegiatan membaca diperlukan pengetahuan tentang sistem penulisan, khususnya yang menyangkut huruf dan ejaan (Nurgiyantoro, 2001).

Soedarso (Perangin-angin, 2013) menyatakan bahwa membaca adalah aktivitas yang kompleks dengan mengarahkan sejumlah besar tindakan yang terpisah-pisah, meliputi: orang harus menggunakan pengertian dan khayalan, mengamati dan mengingatingat. Kita tidak dapat membaca tanpa menggerakkan mata atau tanpa menggunakan pikiran kita.

Membaca adalah satu dari empat kemampuan bahasa pokok dan merupakan satu bagian atau komponen dari komunikasi lisan. Lambanglambang bunyi bahasa diubah menjadi lambang-lambang tulisan atau hurufhuruf, dalam hal ini huruf-huruf menurut alphabet lain (Tampubolon dalam Amalia, 2017). Kemudian membaca juga dikemukakan Bond (dalam Abdurrahman, 2003) bahwa membaca merupakan pengenalan simbol-simbol bahasa tulis yang merupakan stimulus yang membantu proses mengingat tentang apa yang dibaca, untuk membangun suatu pengertian melalui pengalaman yang dimiliki.

Menurut Henry Guntur (1995) membaca adalah suatu proses yang dilakukan serta dipergunakan oleh pembaca untuk memperoleh pesan, yang hendak disampaikan oleh penulis melalui media kata-kata/bahasa tulis. Pengertian membaca dari segi linguistik menurut Anderson (dalam Henry Guntur, 1995) adalah suatu proses penyandian kembali dan pembacaan sandi (a recording and decoding process) berlainan dengan berbicara dan menulis yang justru melibatkan penyandian (encoding). Sebuah aspek pembacaan sandi (decoding) adalah menghubungkan katakata tulis (written word) dengan makna bahasa lisan (oral language meaning) yang mencakup pengubahan tulisan/cetakan menjadi bunyi yang bermakna.

Menurut Simbolon membaca merupakan sesuatu yang rumit yang melibatkan banyak hal, tidak hanya sekedar melafalkan tulisan tetapi juga aktifitas visual, berpikir, psikolinguistik, dan metakognitif. Sebagai proses visual membaca merupakan proses penerjemahan simbol tulis (huruf) kedalam kata-kata lisan sebagai suatu proses berpikir membaca mencakup aktifitas pengenalan kata, pemahaman, membaca kritis, dan pemahaman kreatif.

Tampubolon (1990) menyatakan membaca adalah suatu kegiatan fisik dan mental. Dikatakan kegiatan fisik, karena melibatkan kerja mata dan dikatakan kegiatan mental, karena menuntut kerja pikiran untuk memahami apa yang tertulis. Membaca merupakan keterampilan berbahasa 


Kredo 4 (2021)
KREDO: Jurnal Ilmiah Bahasa dan Sastra
Terakreditasi Sinta 4 berdasarkan Keputusan
Direktorat Jenderal Penguatan Riset dan
Pengembangan, Kementerian Riset, Teknologi dan
Pendidikan Tinggi Republik Indonesia
Nomor: 23/E/KPT/2019.08 Agustus 2019
https://jurnal.umk.ac.id/index.php/kredo/index

yang berhubungan dengan keterampilan berbahasa yang lain. Rahim (2008) mengemukakan bahwa membaca pada hakikatnya adalah suatu yang rumit yang melibatkan banyak hal, tidak hanya sekadar melafalkan tulisan, tetapi juga melibatkan aktivitas visual, berpikir, psikolinguistik, dan metakognitif. Berdasarkan beberapa definisi diatas dapat disimpulkan bahwa membaca adalah proses pengucapan tulisan untuk mendapatkan isinya.

\section{B. Tujuan Membaca}

Tujuan merupakan dasar dari setiap kegiatan dan motivasi yang paling kuat dalam melakukan suatu tindakan. Tujuan membaca secara singkat, yaitu menangkap maksud orang lain dalam bentuk tulisan. Aderson (dalam Tarigan, 2008) memberi suatu pernyataan tentang tujuan dari membaca yakni: (1) untuk mendapatkan fakta-fakta atau perincian-perincian, (2) untuk menemukan beberapa ide yang pokok, (3) susunan atau urutan organisasi suatu cerita dapat diketahui, (4) untuk memberikan suatu kesimpulan dan membaca inferensinya, (5) untuk mengklasifikan atau mengelompokkan, (6) untuk membaca, menilai dan memberi evaluasi, dan (7) untuk memberikan suatu pertentangan atau perbandingan.

\section{9 | Jurnal Kredo}

Vol. 4 No. 22021

\section{Jenis-Jenis Membaca}

1. Membaca Nyaring

Membaca nyaring atau bersuara yaitu membaca yang dilakukan dengan bersuara (Rahim 2008). Sebenarnya apabila kita berpegang pada batasanbatasan tentang membaca, semua perbuatan membaca tentu saja kedengaran orang lain. Perbedaannya terletak pada persoalan berapa jauh suara bacaan dapat didengar orang lain. Istilah membaca keras maksudnya membaca dengan suara nyaring (Perangin-angin 2013). Oleh karena itu adalah istilah, "membaca nyaring". Mengapa harus bersuara keras atau nyaring karena perlu didengar oleh orang lain. Biarpun membaca untuk diri sendiri, bagi anak kelas I mempunyai kebiasaan keras atau nyaring. Tujuan membaca nyaring agar guru dan kawan sekelas dapat menyimak. Dengan menyimak guru dapat memperbaiki bacaan siswa. Pelaksanaan membaca dapat memperbaiki bacaan siswa.

2. Membaca dalam Hati

Membaca dalam hati yaitu membaca dengan tidak mengeluarkan kata-kata atau suara (Nurhadi 1987). Dengan membaca dalam hati siswa dapat lebih berkonsentrasi, sehingga lebih dapat memahami isi yang terkandung dalam sebuah bacaan. Membaca dalam hati sebenarnya membaca bagi orang dewasa atau orang tua. Tidak semua siswa SD dapat membaca dalam hati. Membaca dalam 


Kredo 4 (2021)
KREDO: Jurnal Ilmiah Bahasa dan Sastra
Terakreditasi Sinta 4 berdasarkan Keputusan
Direktorat Jenderal Penguatan Riset dan
Pengembangan, Kementerian Riset, Teknologi dan
Pendidikan Tinggi Republik Indonesia
Nomor: 23/E/KPT/2019.08 Agustus 2019
https://jurnal.umk.ac.id/index.php/kredo/index

hati siswa SD tetap dilakukan dengan membaca bersuara atau membaca secara berbisik-bisik. Tidak dapat dilaksanakan secara sempurna (Zuchdi 2008).

Khusus kelas I dan kelas II tidak ada pembelajaran membaca dalam hati. Kelas III-IV dapat dilatih membaca dengan suara bisik-bisik. Sedang kelas V-VI dapat membaca dalam hati secara lebih baik (Rahim 2008). Konsentrasi fisik maksudnya siswa (pembaca) dapat bebas sikap duduknya. Pandangan mata teramat pada seluruh kalimat yang akan dibaca sebelum mengucapkan (dalam hati) kalimat itu. Konsentrasi mental yaitu memerlukan ekstra penilaian. Pemikiran kita harus tertuju pada bacaan yang sedang dihadapi. Tidak boleh membaca dalam hati dengan pemikiran yang gundah dan kacau. Hasilnya pasti tidak maksimal, bahkan sering tejadi melamun, membayangkan apa yang ada pada angan-angan. Hal ini sering terjadi dan tidak diketahui oleh seorang guru, karena sama-sama dengan posisi diam (Inawati and Sanjaya 2018).

Membaca dalam hati juga berusaha membaca secepat-cepatnya. Antara anak satu bangku saja bisa selesainya tidak secara bersamaan, tergantung konsentrasi si pembaca tersebut. Waktu yang dibutuhkan akan lebih sedikit. Siswa pun akan lebih terkondisi, dengan membaca dalam hati, anak-anak tidak ada yang bermain sendiri. Membaca dalam hati dapat menarik minat para siswa agar lekas mengetahui atau memahami isi bacaan (Rahmi and Marnola 2020). Apabila latihan membaca dalam hati kerap dilaksanakan akan dapat menimbulkan suasana demonstratif dari para siswa untuk lekas dapat mengungkapkan kembali isi bacaan.

3. Membaca Pemahaman

Istilah membaca pemahaman sering disebut membaca intensif, membaca dalam hati, atau membaca telaah isi. Membaca adalah interaksi pemakai bahasa dengan masukkan grafis dalam usaha merekonstruksi pesan yang disampaikan penulis. Sedangkan pemahaman berasal dari kata paham ditambahkan imbuhan (pean) yang artinya mengerti benar atau tahu benar atau ada gambaran yang dimengerti secara lengkap (Amalia 2017).

Menurut Burns (dalam Kamalasari 2012) Secara umum komponen membaca terdiri atas dua komponen, yaitu proses membaca dan produk membaca. Proses membaca terdiri atas tiga komponen dasar yaitu recording, decoding, dan meaning yang dapat diurai menjadi sembilan aspek, yaitu sensori, perseptual, urutan, pengalaman, pikiran, pembelajaran, asosiasi, sikap, dan gagasan. Kesembilan aspek ini saling berhubungan untuk mendukung proses membaca yang baik. Aspek yang 


Kredo 4 (2021)
KREDO: Jurnal Ilmiah Bahasa dan Sastra
Terakreditasi Sinta 4 berdasarkan Keputusan
Direktorat Jenderal Penguatan Riset dan
Pengembangan, Kementerian Riset, Teknologi dan
Pendidikan Tinggi Republik Indonesia
Nomor: 23/E/KPT/2019.08 Agustus 2019
https://jurnal.umk.ac.id/index.php/kredo/index

pertama adalah sensori. Kegiatan sensori adalah pengungkapan simbolsimbol grafis yang digunakan untuk merepresentasikan bahasa lisan melalui indra penglihatan. Kegiatan perseptual merupakan aktivitas mengenal suatu kata sampai pada suatu makna berdasarkan pengalaman yang lalu.

Ketika seseorang membaca, otak menerima gambaran kata-kata kemudian mengungkapkan berdasarkan pengalaman membaca sebelumnya dengan objek, gagasan, dan emosi (Amalia 2017; Rahim 2008). Aspek urutan dalam proses membaca merupakan kegiatan mengikuti rangkaian tulisan yang tersusun secara linear, yang umumnya tampil pada satu halaman dari kiri ke kanan atau dari atas ke bawah. Pengalaman merupakan hal penting pada proses membaca. Anak-anak yang mempunyai banyak pengalaman memiliki peluang yang lebih luas dalam mengembangkan pemahaman kosakata dan konsep yang mereka hadapi dalam membaca dibandingkan dengan anak-anak yang memiliki pengalaman yang terbatas. Membaca merupakan proses berpikir. Pembaca terlebih dahulu memahami kata-kata dan kalimat yang dihadapi melalui proses asosiasi dan eksperimen, kemudian membuat simpulan dengan mengaitkan isi preposisi yang terdapat dalam bacaan (Kamalasari 2012; Laily 2014). Untuk itulah pembaca harus berpikir sistematis, logis, dan kreatif.

481 | Jurnal Kredo

Vol. 4 No. 22021

\section{Hakikat Membaca Pemahaman}

Membaca memahami merupakan kegiatan membaca sesungguhnya, yang ditunjukkan kepada kemampuan memahami bacaan secara tepat dan cepat. Dalam proses membaca ini, terlihat aspek-aspek berpikir seperti mengingat, memahami, membandingkan, menemukan, mengorganisasikan, dan pada akhirnya merupakan sesuatu yang terkandung dalam bacaan (Amalia 2017; Inawati and Sanjaya 2018; Juliantari 2017; Laily 2014; Sulistyowati 2009).

\section{E. Faktor-Faktor Mempengaruhi Pemahaman}

Ada banyak faktor yang dapat mempengaruhi pemahaman keberhasilan seseorang dalam memahami suatu bacaan. Ada dua faktor yang dapat mempengaruhi pemahaman atau komprehensi bacaan yakni faktor dari luar dan di dalam diri pembaca (Johson dan Dearson dalam Zuchdi, 2008).

Adapun faktor yang timbul dari dalam diri seorang pembaca yaitu kemampuan kebahasaan (linguistik), seberapa besar rasa peduli pembaca terhadap bacaan yang dibaca (minat baca), seberapa besar rasa peduli pembaca terhadap perasaan umum atau tugas yang berkaitan dengan membaca dan sekolah (motivasi membaca), dan seberapa baik pembaca dalam membaca 


Kredo 4 (2021)
KREDO: Jurnal Ilmiah Bahasa dan Sastra
Terakreditasi Sinta 4 berdasarkan Keputusan
Direktorat Jenderal Penguatan Riset dan
Pengembangan, Kementerian Riset, Teknologi dan
Pendidikan Tinggi Republik Indonesia
Nomor: 23/E/KPT/2019.08 Agustus 2019
https://jurnal.umk.ac.id/index.php/kredo/index

(kumpulan kemampuan membaca). Sedangkan faktor dari luar pembaca terbagi atas dua bagian yaitu lingkungan membaca dan unsur-unsur bacaan (Kamalasari 2012; Tantri 2017).

\section{F. Teknik Warming Up for Reading}

Teknik ini merupakan teknik yang berupaya untuk menggali pengetahuan dasar peserta didik agar teks bacaan dapat dipahami. Teknik ini sangat sederhana dan salah satu media yang digunakan dalam kegiatannya adalah menggunakan secarik kertas kerja (worksheet). Aktivitas ini bisa dilaksanakan pada berbagai tingkatan usia, jenjang pendidikan dan pada jenis teks apapun (Sequero 1998; Sunarti 2020).

\section{Keunggulan dan Kelemahan Teknik Warming Up for Reading}

\section{a. Keunggulan Teknik Warming Up for Reading}

Melalui penggunaan teknik ini, siswa akan merasa lebih termotivasi dan tertantang dalam melakukan kegiatan membaca. Membaca merupakan suatu kegiatan berpikir, pembaca terlebih dahulu harus mengetahui kalimat dan kosa-kata yang dihadapinya dengan cara proses asosiasi agar dapat memahami suatu bacaan (Burns dalam Rahim, 2008). Maka dari itu pembaca haruslah memiliki pola fikir yang kreatif, logis dan sistematis.

\section{Perlu} diketahui bahwa pembelajaran membaca pemahaman akan lebih bermakna melalui penggunaan teknik ini, sebab perhatian dari peserta didik lebih difokuskan pada inti informasi dalam suatu bacaan. Melalui teknik ini pula siswa dapat melatih penggunaannya di luar lingkungan sekolahnya. Setiap siswa memiliki peran sebagai peserta yang aktif, yang harus membaca suatu teks, lalu pertanyaan dituliskan kemudian memprediksinya. Aktivitas ini sedemikian rupa dibuat agar menjadi suatu aktivitas yang menjadikan siswa sebagai center perhatian.

Setidaknya ada 4 komponen dasar dalam proses membaca melalui pengguaan teknik ini, yaitu: (1) pengembangan suatu kosa-kata, (2) melalui penggunaan teknik ini sebelum diberikan teks terlebih dahulu peserta didik diberikan suatu judul. Sehingga apa yang ada dalam bacaan tersebut dapat dibayangkan oleh peserta didik, (3) siswa akan melakukan antisipasi suatu informasi yang akan diterimanya sehingga proses sintes dan evaluasi terjadi, dan (4) siswa akan mencari informasi yang umum, kemudian informasi tertentu dicari, selanjutnya kesimpulan dibuat dan judul bacaan dipahami dan pada saat bersamaan teknik ini dapat melatih siswa untuk lebih memahami suatu bacaan dan ketika mereka membaca teknik ini selalu digunakan. 


Kredo 4 (2021)
KREDO: Jurnal Ilmiah Bahasa dan Sastra
Terakreditasi Sinta 4 berdasarkan Keputusan
Direktorat Jenderal Penguatan Riset dan
Pengembangan, Kementerian Riset, Teknologi dan
Pendidikan Tinggi Republik Indonesia
Nomor: 23/E/KPT/2019.08 Agustus 2019
https://jurnal.umk.ac.id/index.php/kredo/index

Selain bermanfaat sebagai kegiatan pra-membaca, salah satu manfaat yang dimiliki oleh teknik ini adalah membuat suatu pembelajaran lebih memiliki suatu makna, hal ini terjadi dikarenakan teknik ini mampu menjadikan instrumen untuk mengaktifkan dan menggali kembali pengetahuan dasar yang dimiliki peserta didik.

b. Kelemahan Teknik Warming Up for Reading

Meskipun telah banyak yang mengulas dan memanfaatkan teknik ini dalam pembelajaran membaca dan hasilnya pun memuaskan, namun tidak menutup kemungkinan bahwa teknik ini juga memiliki beberapa kelemahan. Berikut ini dirangkum beberapa kelemahan teknik warming up for reading;

1) Dalam menyusun teknik ini diperlukan suatu keterampilan dan kreativitas.

2) Untuk melakukan teknik ini dibutuhkan waktu yang lama.

3) Ketika teknik ini digunakan maka dibutuhkan seesorang sebagai ketua kelompok untuk mengatur dan menghindari suasana yang ramai (Sequero 1998; Sunarti 2020).

\section{METODE PENELITIAN}

\section{A. Jenis Penelitian}

Sanjaya (2016) dalam penelitian ini peneliti menggunakan prosedur penelitian tindakan kelas atau disingkat
PTK. Penelitian tindakan kelas adalah suatu pencermatan terhadap suatu kegiatan yang sengaja dimunculkan, dan terjadi dalam sebuah kelas. PTK merupakan salah satu cara yang srategis bagi guru untuk memperbaiki layanan kependidikan yang harus diselenggarakan dalam konteks pembelajaran di kelas dan peningkatan kualitas program sekolah secara keseluruhan. Tujuan dari penelitian tindakan kelas adalah untuk memperbaiki dan meningkatkan praktik pembelajaran di kelas secara berkesinambungan (Sanjaya 2016). Oleh karena itu, untuk mencapai tujuan yang diharapkan maka pelaksanaan penelitian ini dilakukan melalui beberapa tahapan yaitu, perencanaan, tindakan, observasi, dan refleksi. Prosedur penelitian ini diadaptasikan dengan kaji tindak (action research).

\section{B. Lokasi dan Subjek Penelitian}

Penelitian tindakan kelas ini akan dilaksanakan di kelas VII semester I (ganjil) SMP Muhammadiyah 5 Makassar. Subjek dalam penelitian adalah siswa kelas VII B SMP Muhammadiyah 5 Makassar berjumlah 34 orang. Berdasarkan hasil observasi awal maka peneliti mengambil responden tersebut dengan alasan bahwa tingkat keterampilan membaca pemahaman kelas VII B SMP Muhammadiyah 5 Makassar masih rendah. Hasil membaca pemahaman 


Kredo 4 (2021)
KREDO: Jurnal Ilmiah Bahasa dan Sastra
Terakreditasi Sinta 4 berdasarkan Keputusan
Direktorat Jenderal Penguatan Riset dan
Pengembangan, Kementerian Riset, Teknologi dan
Pendidikan Tinggi Republik Indonesia
Nomor: 23/E/KPT/2019.08 Agustus 2019
https://jurnal.umk.ac.id/index.php/kredo/index

siswa belum mampu mencapai tingkat pemahaman yang lebih eksplisit terhadap isi bacaan. Maka dari itu, agar dapat meningkatkan keterampilan membaca maka diperlukan suatu strategi pembelajaran yang tepat. Pembelajaran dengan Strategi Warming $U p$ for Reading diharapkan dapat meningkatkan keterampilan siswa dalam membaca pemahaman.

\section{Data dan Sumber Data}

\section{Data Penelitian}

Adapun data dalam penelitian ini berupa data perencanaan, data pelaksanaan, data evaluasi dan data hasil penelitian. Data penelitian ini diperoleh melalui observasi, data dokumentasi, jurnal dan tes setiap tindakan perbaikan penggunaan strategi pembelajaran Warming Up for Reading dalam pembelajaran membaca pemahaman bagi siswa kelas VII B SMP Muhammadiyah 5 Makassar. Data tersebut diuraikan sebagai berikut.

\section{a. Data Perencanaan}

Data perencanaan berupa rancangan pelaksanaan pembelajaran. Rancangan tersebut meliputi rumusan tujuan pembelajaran, penyusunan kegiatan belajar mengajar, materi dan sumber belajar, pemilihan media, dan perencanaan evaluasi. b. Data Pelaksanaan

Data pelaksanaan berkaitan dengan penerapan strategi pembelajaran Warming Up for Reading dalam pembelajaran membaca pemahaman. Data tersebut berdasarkan hasil observasi dan catatan lapangan mengenai pengamatan tentang kegiatan siswa yang dibimbing guru selama proses pembelajaran membaca pemahaman berlangsung hingga guru dan siswa melakukan evaluasi terhadap hasil bacaan.

\section{c. Data Evaluasi}

Data evaluasi meliputi data proses dan data produk. Data proses dilakukan dengan cara mengobservasi kegiatan siswa selama mengikuti pembelajaran yang terdiri atas aspek minat, perhatian, dan partisipasi (Kusnandar dalam Alawiyah 2013). Nilai tertinggi adalah 4 (sangat baik), diikuti 3 (baik), 2 (cukup), dan terendah adalah 1 (kurang).

\section{Sumber Data}

Sumber data penelitian ini ada 2, yaitu sumber data lisan dan tertulis. Sumber data lisan adalah informan yang memiliki pengetahuan tentang cara kerja siswa dalam hal ini guru. Sedangkan, sumber data tertulis adalah hasil kerja siswa kelas VII B SMP Muhammadiyah 5 Makassar. 


Kredo 4 (2021)
KREDO: Jurnal Ilmiah Bahasa dan Sastra
Terakreditasi Sinta 4 berdasarkan Keputusan
Direktorat Jenderal Penguatan Riset dan
Pengembangan, Kementerian Riset, Teknologi dan
Pendidikan Tinggi Republik Indonesia
Nomor: 23/E/KPT/2019.08 Agustus 2019
https://jurnal.umk.ac.id/index.php/kredo/index

\section{Prosedur Pelaksanaan}

Penelitian ini direncanakan selama dua siklus, di mana setiap siklus saling berkaitan dalam hal rangkaian kegiatannya. Artinya, pelaksanaan pada siklus I akan dilanjutkan pada siklus II yang merupakan perbaikan dari siklus I. Siklus I dan II meliputi: (1) perencanaan tindakan, (2) pelaksanaan tindakan, (3) pengamatan, (4) refleksi.

\section{E. Teknik pengumpulan data}

Teknik pengumpulan data adalah cara yang dilakukan dalam mengumpulkan data yang berhubungan dengan penelitian ini. Untuk mengumpulkan data, diperlukan suatu alat penelitian yang akurat karena hasilnya sangat menentukan mutu dan penelitian. Dalam penelitian ini, peneliti menggunakan dua teknik pengumpulan data yaitu teknik tes dan teknik nontes.

\section{Teknik Tes}

Peneliti mengumpulkan data dengan menggunakan tes. Tes ini dilakukan sebanyak dua kali yakni pada kedua siklus dilakukan tes membaca pemahaman melalui strategi pembelajaran Warming Up for Reading. Kekurangan yang terdapat pada siklus pertama harus dapat diperbaiki pada siklus kedua. Dalam penelitian ini siswa melaksanakan tugas secara individu yakni setiap siswa membaca pemahaman pada lembar yang telah disediakan.

485 | Jurnal Kredo

Vol. 4 No. 22021

\section{Teknik Nontes}

a. Teknik interview

Untuk mengungkap data yang menjadi sebab terjadinya hambatan dan kesulitan dalam pembelajaran membaca maka dilakukanlah wawancara. Teknik ini dilaksanakan melalui cara melakukan kegiatan wawancara pada siswa dan guru berkaitan bagaimana kemampuan siswa dan guru dalam melakukan kegiatan pembelajaran membaca yang akan diteliti.

b. Teknik observasi

Teknik dilaksanakan kepada keseluruhan kegiatan peserta didik pada saat berlangsungnya kegiatan pembelajaran. Tujuan dari pelaksanaan kegiatan ini adalah untuk memperoleh data mengenai keaktifan peserta didik selama berlangsungnya kegiatan membaca pemahaman melalui penggunaan teknik Warming Up for Reading. Proses observasi ini ditujujan pada perkembangan pemahaman peserta didik melalui bantuan beberapa pertanyaan pemahaman dan atau kemungkinan peserta didik ikut sera dalam suatu pemecahan masalah atau diskusi.

c. Teknik dokumentasi

Teknik dokumentasi dilakukan dengan cara mengumpulkan data dan menyimpan data atau informasi dari berbagai sumber yang berkaitan erat dengan penelitian ini. Pengambilan data melalui foto dilakukan pada saat proses 


Kredo 4 (2021)
KREDO: Jurnal Ilmiah Bahasa dan Sastra
Terakreditasi Sinta 4 berdasarkan Keputusan
Direktorat Jenderal Penguatan Riset dan
Pengembangan, Kementerian Riset, Teknologi dan
Pendidikan Tinggi Republik Indonesia
Nomor: 23/E/KPT/2019.08 Agustus 2019
https://jurnal.umk.ac.id/index.php/kredo/index

pembelajaran berlangsung. Peneliti meminta bantuan teman untuk mengambil gambar atau mendokumentasikan pembelajaran melalui foto. Foto yang diambil dijadikan sebagai sumber data.

\section{F. Teknik analisis data}

Data pada penelitian ini adalah data hasil kemampuan membaca pemahaman dengan penggunaan strategi pembelajaran Warming Up for Reading siswa serta data yang diperoleh dari hasil observasi dan catatan lapangan. Data tersebut direduksi berdasarkan masalah yang diteliti, diikuti penyajian data, dan terakhir penyimpulan atau verifikasi. Tahap analisis itu diuraikan sebagai berikut:

\section{Menelaah data}

Kegiatan ini dilakukuan dengan cara mengumpulkan data dari berbagai data informasi yang telah didapatkan melalui pengamatan, studi dokumentasi, dan catatan lapangan. Selanjutnya data tersebut dilakukan transkripsi hasil pengamatan, diseleksi dan dilakukan pemilihan data. Sebab data yang telah terkumpul tersebut masih berupa data yang belum diolah (data mentah). Setelah data tesebut diseleksi dan data tesebut dipilah dari data mentah kemudian dilakukan pengelompokkan berdasarkan data pada setiap siklus.

\section{Reduksi data}

Kegiatan ini bertujuan untuk diperolehnya suatu data yang lebih tajam dan fokus, sebab sulit ditemukan gambaran yang jelas apabila data tersebut tertumpuk. Keseluruhan data yang telah dikumpulkan diseleksi dan diidentifikasikan sesuai kelompoknya dan mengklasifikasikannya berdasarkan kebutuhannya.

Kemudian membandingkan hasil perhitungan dari masing-masing siklus. Dengan cara perhitungan ini maka dapat diketahui persentase peningkatan kemampuan membaca pemahaman melalui strategi pembelajaran Warming Up for Reading.

\section{Menyajikan data}

Setelah kegiatan menelaah data dan reduksi data telah dilakukan, selanjutnya dilakukanlah penyajian data. Penyajian data ini dilakukan melalui cara mengorganisasikan informasi yang sudah direduksi sebelumnya. Setelah informasi tesebut direduksi maka disajikan sebagai suatu kumpulan informasi yang disusun yang memberikan kemungkinan adanya suatu penarikan kesimpulan untuk dilakukan suatu tindakan. Selanjutnya data-data tersebut dirangkum dan secara terpadu disajikan sesuai dengan siklus yang telah direncanakan sehingga difokuskan pada pembelajaran.

\section{Menyimpulkan hasil penelitian}

$$
\text { Pada tahap ini dilakukan }
$$
penarikan kesimpulan pada akhir temuan penelitian dan melakukan kegiatan pengujian temuan penelitian atau tringulasi data. Selanjutnya 


Kredo 4 (2021)
KREDO: Jurnal Ilmiah Bahasa dan Sastra
Terakreditasi Sinta 4 berdasarkan Keputusan
Direktorat Jenderal Penguatan Riset dan
Pengembangan, Kementerian Riset, Teknologi dan
Pendidikan Tinggi Republik Indonesia
Nomor: 23/E/KPT/2019.08 Agustus 2019
https://jurnal.umk.ac.id/index.php/kredo/index

melakukan pengujian keabsahan data dengan memikir ulang berbagai hal yang telah dilalui dan mengemukakannya dengan cara saling menukar pendapat dengan pembimbing dan ahli, rekan sejawat, peninjauan ulang catatan lapangan, hasil pengamatan, dan triangulasi dengan guru atau teman sejawat setelah kegiatan pembelajaran selesai. Penerapan strategi pembelajaran Warming Up for Reading dalam upaya peningkatan kemampuan membaca pemahaman pada siswa kelas VII B SMP Muhammadiyah 5 Makassar dikaitkan dengan ketuntasan belajar. Siswa yang mendapatkan nilai 75 ke atas maka pembelajaran membaca pemahaman dengan strategi pembelajaran Warming Up for Reading oleh guru dapat berhasil efektif. Taraf keberhasilan yang dicapai siswa dikatakan berhasil apabila mencapai nilai baik dan sangat baik.

\section{Kriteria Penilaian}

Kemampuan siswa dalam membaca didasarkan pada lima hal pokok, yaitu:
a. Ketepatan
b. Kesesuian jawaban
c. Kejelasan
d. Kelengkapan

\section{HASIL DAN PEMBAHASAN}

\section{A. Hasil Penelitian}

Pada bagian ini akan di bahas hasil-hasil penilaian mengenai

\section{7 | Jurnal Kredo}

Vol. 4 No. 22021 peningkatan kemampuan membaca pemahaman melalui teknik Warming $U p$ for Reading pada siswa kelas VII B SMP Muhammadiyah 5 Makassar dari siklus I ke siklus II dengan menggunakan analisis kualitatif, yaitu data tentang hasil pengamatan sedangkan tentang hasil belajar siswa di analisis secara kuantitatif dengan menggunakan deskriptif kualitatif. Adapun yang dianalisis adalah pelaksanaan tindakan pada siklus I dan siklus II.

Tabel 1. Daftar Skor Hasil Evaluasi Siswa pada Siklus I

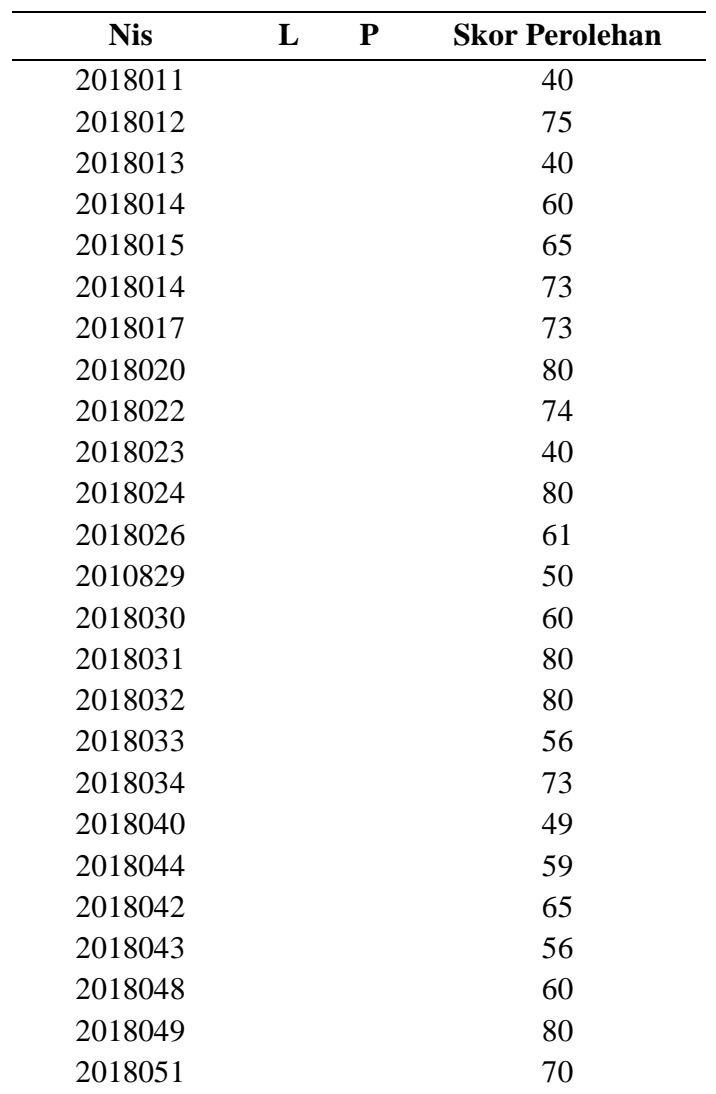




Kredo 4 (2021)
KREDO: Jurnal Ilmiah Bahasa dan Sastra
Terakreditasi Sinta 4 berdasarkan Keputusan
Direktorat Jenderal Penguatan Riset dan
Pengembangan, Kementerian Riset, Teknologi dan
Pendidikan Tinggi Republik Indonesia
Nomor: 23/E/KPT/2019. 08 Agustus 2019
https://jurnal.umk.ac.id/index.php/kredo/index

$\begin{array}{ll}2018052 & 71 \\ 2018053 & 74 \\ 2018055 & 60 \\ 2018068 & 64 \\ 2018070 & 80 \\ 2018071 & 50 \\ 2018072 & 80 \\ 2018073 & 70 \\ 2018078 & 75 \\ 2018079 & 80\end{array}$

Tabel 2. Distribusi Frekuensi Skor Evaluasi Siswa pada Siklus I

\begin{tabular}{cccc}
\hline Skor & Kategori & Frekuensi & $\begin{array}{c}\text { Persentase } \\
(\mathbf{\%})\end{array}$ \\
\hline $87-98$ & $\begin{array}{c}\text { Sangat } \\
\text { tinggi }\end{array}$ & - & \\
$75-86$ & Tinggi & 13 & 38,23 \\
$63-74$ & Sedang & 8 & 23,52 \\
$51-62$ & Rendah & 7 & 20,58 \\
$<50$ & Rendah & 6 & 17,64 \\
& sekali & & \\
\hline Jumlah & & $\mathbf{3 4}$ & $\mathbf{1 0 0}$
\end{tabular}

Dari tes siklus I pada tabel 1 di atas tergambar bahwa dari 34 siswa kelas VII B SMP Muhammadiyah 5 Makassar, 21 siswa atau 61,76\% belum mencapai batas ketuntasan, sedangkan yang mencapai batas tuntas yaitu 13 siswa atau hanya $38,23 \%$, nilai rata-rata seluruh siswa, yaitu $66,83 \%$ sehingga dikategorikan rendah.

Tabel 3. Hasil Observasi Aktivitas Proses Pembelajaran pada Siklus I

\begin{tabular}{|c|c|c|c|c|c|c|}
\hline \multirow[b]{2}{*}{$\begin{array}{l}\mathbf{N} \\
\mathbf{o}\end{array}$} & \multirow{2}{*}{$\begin{array}{c}\text { Kompone } \\
\text { n yang } \\
\text { Diamati }\end{array}$} & \multicolumn{4}{|c|}{ Pertemuan } & \multirow[b]{2}{*}{$\begin{array}{c}\text { Persentase } \\
(\%)\end{array}$} \\
\hline & & I & II & $\begin{array}{c}\text { II } \\
\text { I }\end{array}$ & IV & \\
\hline 1 & $\begin{array}{l}\text { Siswa } \\
\text { yang hadir } \\
\text { saat } \\
\text { pembelaja } \\
\text { ran. }\end{array}$ & 29 & 30 & 34 & $\sum_{\substack{2 \\
2}}^{2}$ & 91,17 \\
\hline 2 & $\begin{array}{l}\text { Siswa } \\
\text { yang } \\
\text { memperha }\end{array}$ & 26 & 29 & 30 & 预 & 83,33 \\
\hline
\end{tabular}

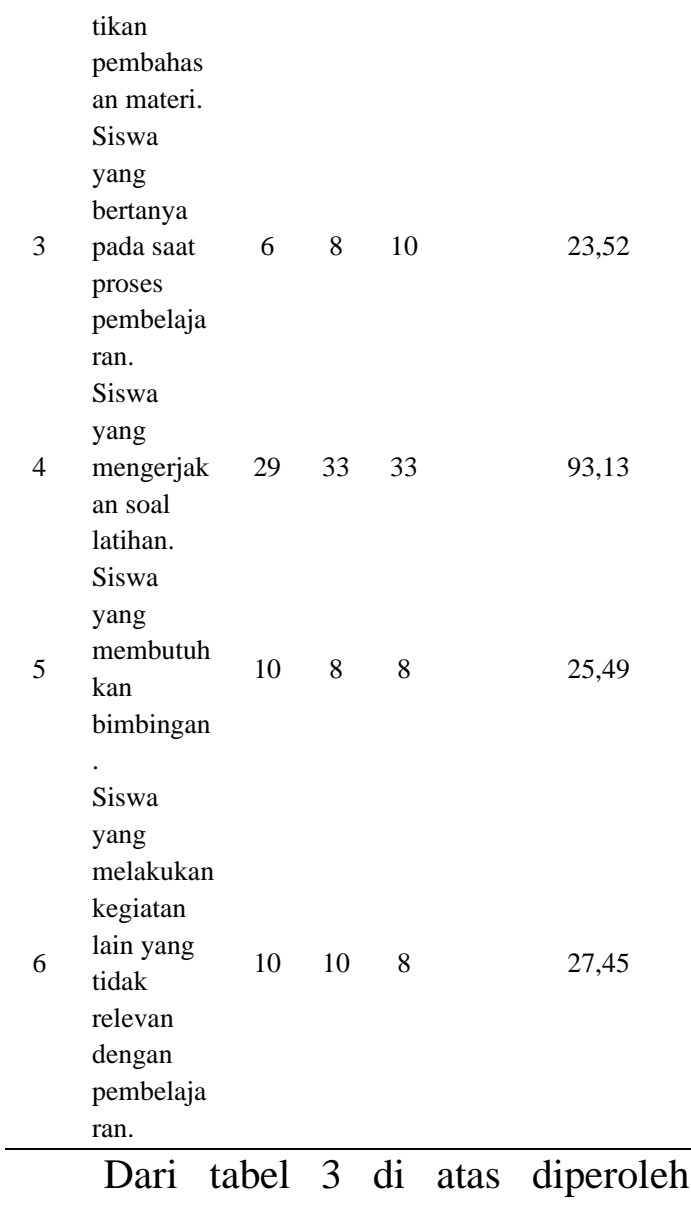

bahwa dari 34 siswa kelas VII B SMP Muhammadiyah 5 Makassar, frekuensi kehadiran siswa tergolong tinggi yaitu 91,17\%. Siswa yang memerhatikan pembahasan materi, yaitu $83,33 \%$, yang mengajukan pertanyaan mengenai materi yang telah dijelaskan rata-rata mencapai 23,52\%, siswa yang mengerjakan soal latihan rata-rata mencapai 93,13\%, siswa yang membutuhkan bimbingan yaitu 25,49\%, siswa yang melakukan kegiatan lain yang tidak relevan dengan pembelajaran mencapai

$27,45 \%$. 


Kredo 4 (2021)
KREDO: Jurnal Ilmiah Bahasa dan Sastra
Terakreditasi Sinta 4 berdasarkan Keputusan
Direktorat Jenderal Penguatan Riset dan
Pengembangan, Kementerian Riset, Teknologi dan
Pendidikan Tinggi Republik Indonesia
Nomor: 23/E/KPT/2019.08 Agustus 2019
https://jurnal.umk.ac.id/index.php/kredo/index

Tabel 4. Daftar Skor Hasil Evaluasi Siswa pada Siklus II.

\begin{tabular}{|c|c|c|c|}
\hline Nis & $\mathbf{L}$ & $\mathbf{P}$ & Skor Perolehan \\
\hline 2018011 & $\checkmark$ & & 70 \\
\hline 2018012 & $\checkmark$ & & 75 \\
\hline 2018013 & $\checkmark$ & & 68 \\
\hline 2018014 & $\checkmark$ & & 70 \\
\hline 2018015 & & $\checkmark$ & 75 \\
\hline 2018014 & $\checkmark$ & & 79 \\
\hline 2018017 & $\checkmark$ & & 80 \\
\hline 2018020 & $\checkmark$ & & 83 \\
\hline 2018022 & & $\checkmark$ & 85 \\
\hline 2018023 & & $\checkmark$ & 74 \\
\hline 2018024 & & $\checkmark$ & 83 \\
\hline 2018026 & & $\checkmark$ & 87 \\
\hline 2018029 & $\checkmark$ & & 65 \\
\hline 2018030 & & $\checkmark$ & 77 \\
\hline 2018032 & & $\checkmark$ & 92 \\
\hline 2018033 & $\checkmark$ & & 60 \\
\hline 2018034 & & $\checkmark$ & 76 \\
\hline 2018040 & $\checkmark$ & & 70 \\
\hline 2018044 & $\checkmark$ & & 80 \\
\hline 2018042 & $\checkmark$ & & 90 \\
\hline 2018043 & $\checkmark$ & & 77 \\
\hline 2018048 & $\checkmark$ & & 77 \\
\hline 2018049 & $\checkmark$ & & 90 \\
\hline 2018051 & $\checkmark$ & & 80 \\
\hline 2018052 & $\checkmark$ & & 76 \\
\hline 2018053 & $\checkmark$ & & 80 \\
\hline 2018055 & & $\checkmark$ & 88 \\
\hline 2018068 & & $\checkmark$ & 88 \\
\hline 2018070 & & $\checkmark$ & 90 \\
\hline 2018071 & $\checkmark$ & & 70 \\
\hline 2018072 & & $\checkmark$ & 95 \\
\hline 2018073 & & $\checkmark$ & 87 \\
\hline 2018078 & & $\checkmark$ & 88 \\
\hline 2018079 & & $\checkmark$ & 95 \\
\hline
\end{tabular}

Tabel 5. Distribusi Frekuensi Skor Evaluasi Siswa pada Siklus II.

\begin{tabular}{|c|c|c|c|}
\hline Skor & Kategori & Frekuensi & Persentase \\
\hline $87-98$ & $\begin{array}{c}\text { Sangat } \\
\text { tinggi }\end{array}$ & 10 & 29,41 \\
\hline $75-86$ & Tinggi & 16 & 50 \\
\hline $63-74$ & Sedang & 7 & 20,58 \\
\hline $51-62$ & Rendah & 1 & 2,94 \\
\hline$<50$ & $\begin{array}{l}\text { Sangat } \\
\text { tendah }\end{array}$ & - & - \\
\hline
\end{tabular}

489 | Jurnal Kredo

Vol. 4 No. 22021

\begin{tabular}{lcc}
\hline Jumlah & $\mathbf{3 4}$ & $\mathbf{1 0 0}$ \\
\hline Dari tes siklus II pada tabel 8
\end{tabular}
tergambar bahwa dari 34 siswa kelas VII B SMP 5 Muhammadiyah Makassar, 8 siswa atau $23,52 \%$ belum mencapai batas ketuntasan, sedang yang mencapai batas tuntas sebanyak 26 siswa atau hanya $76,47 \%$, nilai rata-rata seluruh siswa yaitu $80,88 \%$ sehingga dikategorikan tinggi.

\section{Hasil Observasi}

Seperti pada siklus I, pada siklus II ini juga dilakukan pengamatan aktivitas siswa pada lembar observasi untuk mencatat kejadian-kejadian yang terjadi selama proses belajar mengajar berlangsung. Hasil observasi aktivitas belajar pada siklus II ditampilkan dalam tabel berikut.

Tabel 6. Hasil Observasi aktivitas proses pembelajaran pada siklus II

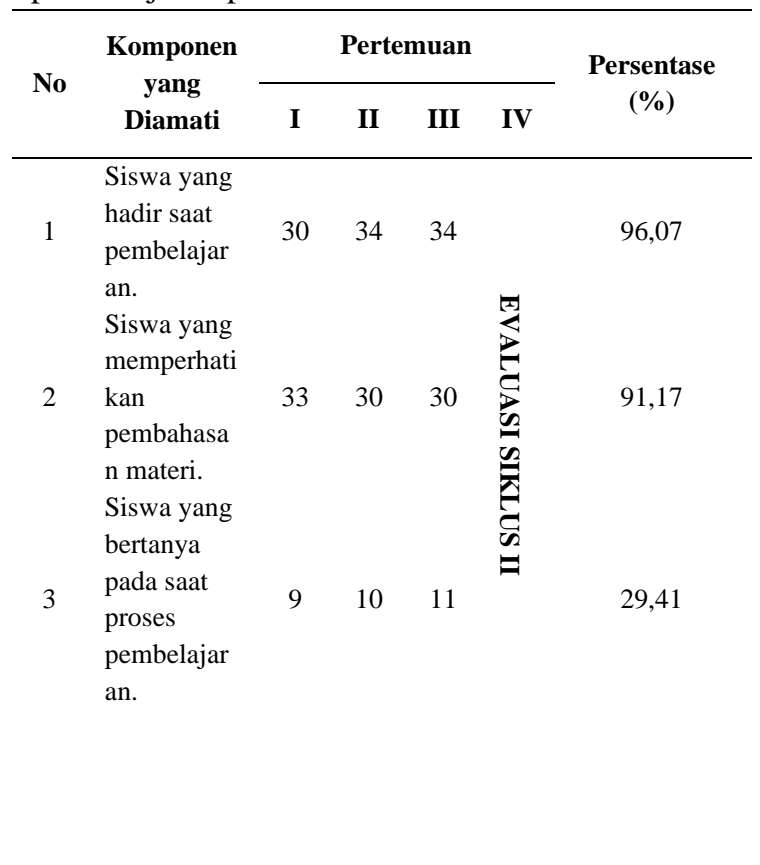




Kredo 4 (2021)
KREDO: Jurnal Ilmiah Bahasa dan Sastra
Terakreditasi Sinta 4 berdasarkan Keputusan
Direktorat Jenderal Penguatan Riset dan
Pengembangan, Kementerian Riset, Teknologi dan
Pendidikan Tinggi Republik Indonesia
Nomor: 23/E/KPT/2019.08 Agustus 2019
https://jurnal.umk.ac.id/index.php/kredo/index

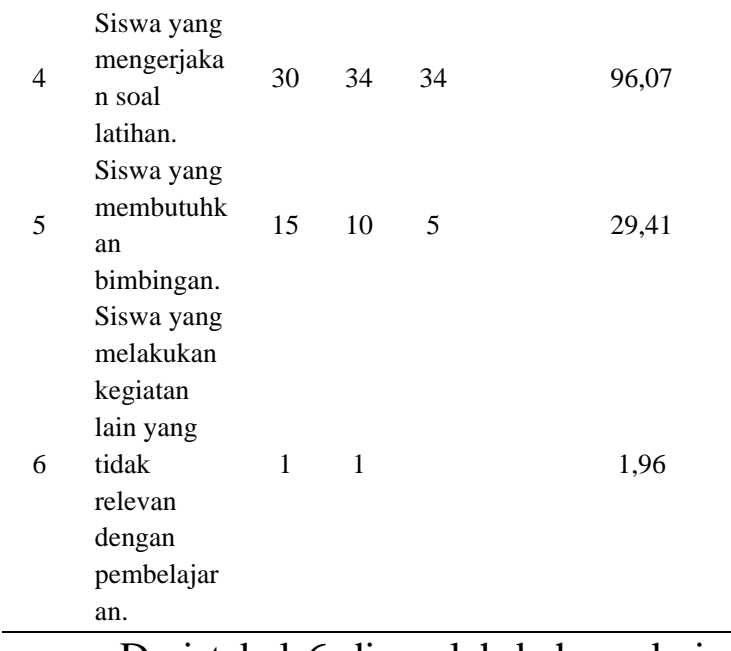

Dari tabel 6 diperoleh bahwa dari

34 siswa kelas VII B SMP 5

Muhammadiyah Makassar, frekuensi kehadiran siswa meningkat menjadi 96,07\%. Siswa yang memerhatikan pembahasan materi meningkat menjadi $91,17 \%$, yang mengajukan pertanyaan mengenai materi yang telah dijelaskan meningkat menjadi $29,41 \%$. Siswa yang mengerjakan soal latihan juga meningkat mencapai $96,07 \%$, siswa yang membutuhkan bimbingan menurun menjadi $29,41 \%$, sedangkan siswa yang melakukan kegiatan lain yang tida relevan dengan pembelajaran menurun menjadi $1,96 \%$.

\section{B. Pembahasan}

Seperti yang dijelaskan sebelumnya bahwa data yang diperoleh dari hasil tes belajar dianalisis dengan menggunakan statistif deskriptif, sedangkan hasil observasi dari hasil angket respon siswa dianalisis secara kualitatif deskriptif.

\section{Analisis Hasil Evaluasi}

Tabel 7. Perbandingan Hasil Evaluasi Membaca Pemahaman Siswa pada Siklus I dan II

\begin{tabular}{cccccccc}
\hline & \multicolumn{4}{c}{ Nilai Perolehan Siswa $(\mathbf{n = 3 0})$} & \multicolumn{2}{c}{$\begin{array}{c}\text { Persentase } \\
(\%)\end{array}$} \\
\cline { 2 - 8 } No & $\begin{array}{c}\text { Mak } \\
\text { s }\end{array}$ & Min & $\begin{array}{c}\text { Mea } \\
\text { n }\end{array}$ & $\begin{array}{c}\text { Nilai } \\
\text { Vari } \\
\text { ansi }\end{array}$ & $\begin{array}{c}\text { Standar } \\
\text { Deviasi }\end{array}$ & $\begin{array}{c}\text { Tunt } \\
\text { as }\end{array}$ & $\begin{array}{c}\text { Tidak } \\
\text { tunta } \\
\text { s }\end{array}$ \\
\hline I & 80 & 40 & 66,87 & $\begin{array}{c}158,9 \\
1\end{array}$ & 12,60 & 21 & 13 \\
\hline II & 95 & 60 & 80,88 & 42,45 & 6,51 & 26 & 8 \\
\hline
\end{tabular}

Tabel 7 menunjukkan bahwa skor rata-rata (mean) kemampuan membaca pemahaman setelah diterapkan teknik pembelajaran Warming Up for Reading mengalami peningkatan yakni dari $66,87 \%$ menjadi $80,88 \%$ dari skor ideal yang mungkin dicapai yaitu $100 \%$. Begitu pula ketuntasan belajar siswa yang mengalami peningkatan dari siklus I ke siklus II.

\section{Analisis hasil Observasi}

Data aktivitas siswa pada siklus I dan II diperoleh melalui hasil observasi selama pembelajaran berlangsung di setiap pertemuan. Adapun perbandingan deskripsi aktivitas siswa pada siklus I dan II dapat dilihat pada tabel berikut.

Tabel 8. Perbandingan aktivitas proses pembelajaran siswa pada siklus I dan II.

\begin{tabular}{llcc}
\hline \multirow{2}{*}{ No } & \multirow{2}{*}{$\begin{array}{c}\text { Komponen yang } \\
\text { Direspons }\end{array}$} & \multicolumn{2}{c}{ Persentase (\%) } \\
\cline { 3 - 4 } & \multicolumn{2}{c}{$\begin{array}{c}\text { Siklus } \\
\text { I }\end{array}$} & $\begin{array}{c}\text { Siklus } \\
\text { II }\end{array}$ \\
\hline \multirow{2}{*}{1} & $\begin{array}{l}\text { Siswa yang hadir pada saat } \\
\text { pembelajaran. }\end{array}$ & 91,17 & 96,07
\end{tabular}




Kredo 4 (2021)
KREDO: Jurnal Ilmiah Bahasa dan Sastra
Terakreditasi Sinta 4 berdasarkan Keputusan
Direktorat Jenderal Penguatan Riset dan
Pengembangan, Kementerian Riset, Teknologi dan
Pendidikan Tinggi Republik Indonesia
Nomor: 23/E/KPT/2019. 08 Agustus 2019
https://jurnal.umk.ac.id/index.php/kredo/index

\begin{tabular}{llll}
2 & $\begin{array}{l}\text { Siswa yang } \\
\text { memperhatikan } \\
\text { pembahasan materi. }\end{array}$ & 83,33 & 91,17 \\
3 & $\begin{array}{l}\text { Siswa yang bertanya pada } \\
\text { saat proses pembelajaran. } \\
\text { Siswa yang mengerjakan }\end{array}$ & 23,52 & 29,41 \\
4 & $\begin{array}{l}\text { soal latihan } \\
\text { Siswa yang membutuhkan } \\
\text { bimbingan }\end{array}$ & 96,07 \\
& $\begin{array}{l}\text { Siswa yang melakukan } \\
\text { kegiatan lain yang tidak } \\
\text { relevan 25,49 } \\
\text { pembelajaran. dengan }\end{array}$ & 29,41 \\
\hline
\end{tabular}

Berdasarkan tabel 7 di atas, maka dapat dikatakan bahwa terdapat beberapa aktivitas yang mengalami peningkatan seperti kehadiran siswa, siswa yang memerhatikan pembahasan materi, siswa yang bertanya dan siswa yang mengerjakan soal latihan. Siswa yang membutuhkan bimbingan dan siswa yang melakukan kegiatan lain yang tidak relevan dengan pembelajaran mengalami penurunan.

Hasil penelitian ini sejalan dengan beberapa hasil penelitian terdahulu (seperti Fradkin, Zazryn, and Smoliga 2010; Sequero 1998; Sunarti 2020) yang menyatakan bahwa teknik Warming $U p$ for Reading efektif untuk meningkatkan kompetensi membaca peserta didik. Dengan teknik Warming Up for Reading siswa akan melatih kemampuan membacanya hingga pada tingkatan yang diharapkan. Tidak heran jika teknik ini menjadi rekomendasi kebanyakan peneliti bahasa jika menghendaki peningkatan kemampuan membaca pada diri peserta didik.
Penggunaan teknik Warming $U p$ For Reading (WFR) dapat digunakan dalam pembelajaran membaca pemahaman untuk dapat mencapai tujuan pembelajaran. Penggunaan teknik Warming Up For Reading (WFR) dalam pembelajaran membuat siswa lebih berfikir aktif dan kreatif, dan dapat menumbuhkan sikap ingin memahami bacaan. Teknik pada dasarnya adalah sebuah cara untuk membantu siswa dalam mendapatkan pemahaman bacaan secara utuh sesuai dengan Taxonomi Ruddel. Berdasarkan data yang disampaikan di atas, penggunaan teknik Warming Up For Reading (WFR) terbukti efektif untuk dapat meningkatkan kemampuan membaca pemahaman pada siswa. Hasil penelitian ini mendukung teori yang telah dikemukakan dan sesuai dengan tujuan penelitian, yaitu untuk mengetahui perbedaan kemampuan membaca pemahaman setelah penerapan teknik Warming Up For Reading (WFR) dalam pembelajaran membaca pemahaman siswa

\section{SIMPULAN DAN SARAN}

\section{SIMPULAN}

Berdasarkan hasil penelitian dan pembahasan yang telah dikemukakan di atas dapat disimpulkan sebagai berikut:

1. Kemampuan membaca pemahaman siswa kelas VII B SMP Muhammadiyah 5 Makassar setelah 


Kredo 4 (2021)
KREDO: Jurnal Ilmiah Bahasa dan Sastra
Terakreditasi Sinta 4 berdasarkan Keputusan
Direktorat Jenderal Penguatan Riset dan
Pengembangan, Kementerian Riset, Teknologi dan
Pendidikan Tinggi Republik Indonesia
Nomor: 23/E/KPT/2019.08 Agustus 2019
https://jurnal.umk.ac.id/index.php/kredo/index

menerapkan teknik pembelajaran Warming Up for Reading mengalami peningkatan, dilihat dari rata-rata yang diperoleh pada siklus I yaitu sebesar $66,87 \%$, sedang pada siklus II sebesar $80,88 \%$. Ditinjau dari ketuntasan individu juga meningkat dari 21 orang siswa pada siklus I menjadi 26 orang siswa pada siklus II.

2. Keaktifan siswa dalam proses belajar mengajar mengalami peningkatan dalam hal kehadiran siswa dalam proses belajar mengajar, perhatian siswa dalam memperhatikan materi pelajaran, keaktifan siswa dalam menyelesaikan tugas-tugas, serta keberanian siswa untuk bertanya dan mengeluarkan pendapat juga semakin meningkat.

\section{SARAN}

Berdasarkan kesimpulan yang diperoleh dari penelitian ini, maka penulis mengajukan saran sebagai berikut:
1. Kepada para peneliti dalam bidang pendidikan Bahasa dan Sastra Indonesia agar melaksanakan penelitian ini lebih lanjut, dengan menyediakan waktu yang banyak agar pelaksanaannya lebih efektif.

2. Kepada siswa, hendaknya terus berlatih meningkatkan keterampilan membaca pemahaman.

3. Untuk meningkatkan hasil belajar, khususnya kemampuan membaca pemahaman siswa diharapkan guru menerapkan teknik pembelajaran Warming Up for Reading.

4. Kepada pihak yang berwenang dalam bidang pendidikan kiranya dapat mengupayakan kelengkapan sarana mengajar, terutama dalam mengajarkan materi pelajaran pada umumnya dan materi bahasa Indonesia pada

khususny

\section{DAFTAR PUSTAKA}

Abdurrahman, Mulyono. 2003. Pendidikan Bagi Anak Berkesulitan Belajar. Jakarta: Rineka Cipta.

Agunawan, Didik. 2009. Peningkatan Kemampuan Membaca Cepat dengan Teknik Skimming dan Scanning pada Siswa Kelas XI IPS 1 SMA Negeri 2 Rembang Tahun Ajaran 2008/2009. Tesis. Universitas Negeri Semarang.

Alawiyah, Faridah. 2013. Peran Guru dalam Kurikulum 2013. Aspirasi: Jurnal Masalah-masalah Sosial 4(1): 65-74. 


Kredo 4 (2021)
KREDO: Jurnal Ilmiah Bahasa dan Sastra
Terakreditasi Sinta 4 berdasarkan Keputusan
Direktorat Jenderal Penguatan Riset dan
Pengembangan, Kementerian Riset, Teknologi dan
Pendidikan Tinggi Republik Indonesia
Nomor: 23/E/KPT/2019.08 Agustus 2019
https://jurnal.umk.ac.id/index.php/kredo/index

Amalia, Falina Noor. 2017. Kemampuan Membaca Pemahaman Mahasiswa. In Seminar Nasional Pendidikan Bahasa Indonesia.

Fradkin, Andrea J, Tsharni R Zazryn, and James M Smoliga. 2010. Effects of Warmingup on Physical Performance: A Systematic Review with Meta-Analysis. The Journal of Strength \& Conditioning Research 24(1): 140-48.

Henry Guntur, Tarigan. 1995. Membaca Sebagai Suatu Keterampilan Berbahasa. Bandung: Angkasa.

Inawati, Inawati, and Muhamad Doni Sanjaya. 2018. Kemampuan Membaca Cepat dan Pemahaman Siswa Kelas v SD Negeri OKU. Jurnal Bindo Sastra 2(1): 173-82.

Juliantari, Ni Kadek. 2017. Paradigma Analisis Wacana dalam Memahami Teks dan Konteks untuk Meningkatkan Kemampuan Membaca Pemahaman. Acarya Pustaka 3(1): $12-25$.

Kamalasari, Vidya. 2012. Latihan Membaca Cepat sebagai upaya Meningkatkan Kemampuan Membaca Cepat dan Pemahaman Bacaan. Basastra 1(1).

Laily, Idah Faridah. 2014. Hubungan Kemampuan Membaca Pemahaman dengan Kemampuan Memahami Soal Cerita Matematika Sekolah Dasar. Eduma: Mathematics Education Learning and Teaching 3(1).

Nurgiyantoro, Burhan. 2001. Penilaian dalam Pengajaran Bahasa dan Sastra. BPFEYogyakarta.

Nurhadi, Drs. 1987. Membaca Cepat dan Efektif. Bandung: Sinar Baru

Perangin-angin, Laurensia Masri. 2013. Meningkatkan Kemampuan Membaca Cepat Siswa Sekolah Dasar. Jurnal Handayani 1(1): 108-28.

Rahim, Farida. 2008. Pengajaran Membaca di Sekolah Dasar. Jakarta: Bumi Aksara.

Rahmi, Yulia, and Ilham Marnola. 2020. Peningkatan Kemampuan Membaca Pemahaman Siswa melalui Model Pembelajaran Cooperative Integrated Reading and Compotion (CIRC). Jurnal basicedu 4(3): 662-72. 


Kredo 4 (2021)
KREDO: Jurnal Ilmiah Bahasa dan Sastra
Terakreditasi Sinta 4 berdasarkan Keputusan
Direktorat Jenderal Penguatan Riset dan
Pengembangan, Kementerian Riset, Teknologi dan
Pendidikan Tinggi Republik Indonesia
Nomor: 23/E/KPT/2019.08 Agustus 2019
https://jurnal.umk.ac.id/index.php/kredo/index

Sanjaya, D R H Wina. 2016. Penelitian Tindakan Kelas. Prenada Media.

Sequero, Wilfredo. 1998. A Ready-Made Reading Class: Warming-Up for Reading. In Forum, ERIC, n4.

Simbolon, Redina. 2019. Penggunaan Roda Pintar Untuk Kemampuan Membaca Anak. Jurnal Pendidikan dan Pengajaran Guru Sekolah Dasar (JPPGuseda) 2(2): 66-71.

Sulistyowati, Rinda Agus. 2009. Peningkatan Keterampilan Membaca Pemahaman Dengan Metode CIRC Pada Siswa Kelas VIII A MTs Negeri Borobudur Kabupaten Magelang Tahun Ajaran 2008/2009. Tesis. Universitas Negeri Semarang.

Sunarti, Sunarti. 2020. Warming up for Reading in Order to Increase Students Reading Skill. International Journal of Secondary Education 8(4): 121.

Tampubolon, Daulat Purnama. 1990. Kemampuan Membaca: Teknik Membaca Efektif dan Efisien. Bandung: Angkasa.

Tantri, Ade Asih Susiari. 2017. Cara Memaksimalkan Kemampuan Membaca Cepat. Acarya Pustaka: Jurnal Ilmiah Perpustakaan dan Informasi 1(2).

Tarigan, Henry Guntur. 2008. Berbicara sebagai Suatu Ketrampilan Berbahasa. Bandung: Angkasa.

Zuchdi, Darmiyati. 2008. Strategi Meningkatkan Kemampuan Membaca: Peningkatan Komprehensi. Yogyakarta: UNY Pres. 